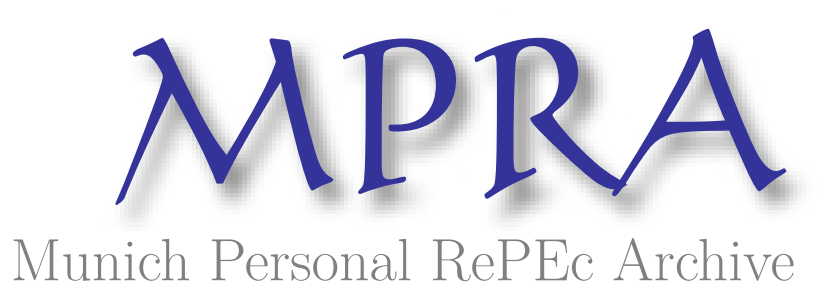

\title{
How to Deal with a Coronavirus Economic Recession?
}

Popov, Vladimir

CEMI

18 May 2020

Online at https://mpra.ub.uni-muenchen.de/100485/

MPRA Paper No. 100485, posted 18 May 2020 21:27 UTC 


\title{
How to Deal with a Coronavirus Economic Recession?
}

\section{Vladimir Popov}

\begin{abstract}
2020 world economic downturn associated with the restrictions intended to fight COVID-19 pandemic is a structural recession caused by adverse supply shock. It is similar to recessions caused (or aggravated) by post war conversion of defense industries, by oil price shocks (1973, 1979, 2007), and by the transition to the market in post-communist countries in the 1990s (transformational recession). Whereas traditional Keynesian policy (absorption of adverse supply shock by means of expansionary fiscal and monetary policy) can help, best results are achieved by government industrial policies promoting restructuring - transferring resources (capital and labor) from the contracting industries to the expanding. The experience of China and some other East Asian countries that seem to be more successful in overcoming the coronavirus recession provides additional evidence.
\end{abstract}

Keywords: Structural recession, adverse supply shock, demand shock, conventional Keynesian response to recession, restructuring, industrial policy

JEL: E32, E6, E65, O25, P20, P51. 


\section{How to Deal with a Coronavirus Economic Recession?}

\section{Vladimir Popov}

The economic recession caused by the COVID-19 pandemic is likely to become the deepest since the Great Depression of the 1930s. Its magnitude is exceeding the scale of the Great Recession of 2008-09. Many economists have already suggested that COVID-19 global crisis will give an additional push to the growing state involvement into economic and social life. In words of Dani Rodrik, "there is nothing like a pandemic to highlight markets' inadequacy in the face of collectiveaction problems and the importance of state capacity to respond to crises and protect people" (Rodrik, 2020).

One area where the greater state involvement is desirable and likely, is the use of industrial policy as the anticyclical tool for fighting the downturns. This recession is different from most of the postwar recessions - it is caused by the supply shock, not by the demand shock, and the policies to bring the economy back to the equilibrium with full employment should differ from traditional Keynesian fiscal and monetary stimuli.

East Asian countries, especially China, seem to be doing better than the others not only in fighting the pandemic, but also in overcoming economic recession. Their experience in economic policy making may be no less valuable than in the public health domain.

\section{Deeper than the Great Recession}

The postwar economic recessions were very mild - on an annual basis US GDP did not fall more than 1 to 2 percent. Even in the last recession of 2008-09, which is believed to be very special and is even called the Great Recession, the reduction of GDP totaled only $0.1 \%$ in 2008 and $2.5 \%$ in 2009 (fig. 1).

The coronavirus recession is likely to cause a greater reduction of GDP. At the time of writing (May 2020) the released data for the first quarter of 2020 showed a 3.5\% decline at annual rate in 
the EU, 4,8\% in the US and 6.8\% in China. GDP in Hubei province (Wuhan, where the virus was first detected, is the capital) fell by nearly $40 \%$ (!) And in all other 33 administrative units of China (except only Tibet) the GDP in the first quarter fell as well. Chinese economy, however, started to recover already in March, so the second quarter is likely to be better than the first, whereas in Europe and the United States the major reduction of output is expected in the second quarter and may be even afterwards.

Figure 1. US GDP annual growth rates, \%

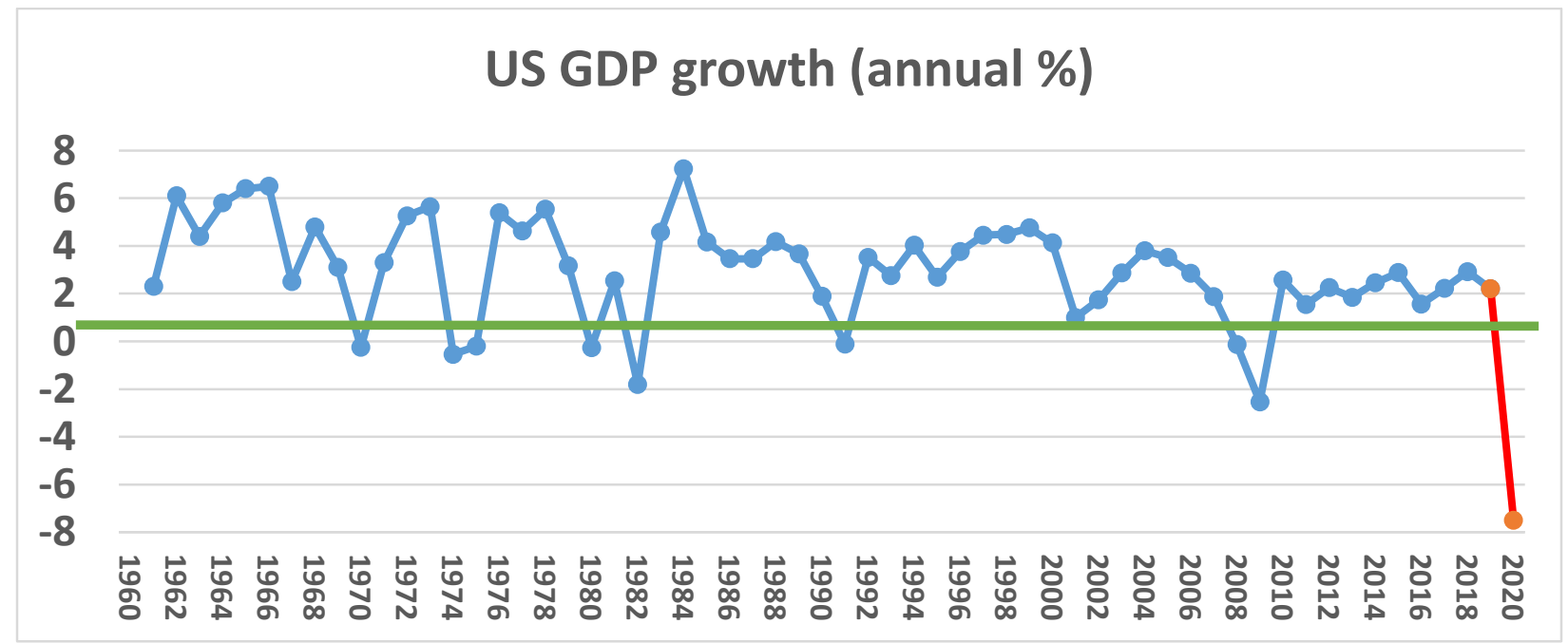

Source: World Development Indicators database.

If the reduction of output in major Western countries in 2020 will total 5 to $10 \%$, this will be the deepest recession of the postwar period and could be compared with the Great Depression of the 1930s. The US GDP at that time fell for full 4 years in a row and in 1933 was about $30 \%$ lower than in 1929. It recovered to the pre-recession 1929 level only in 1936, but then fell in the recession of 1937-38 (fig. 2).

Unemployment rate in the US in the postwar period never exceeded $10 \%$ of the labor force (fig. 3), whereas at the end of the Great Depression it exceeded 20\% of the labor force (fig. 3). In April 2020 the US unemployment rate rose to $14.7 \%$ and was expected to rise even more in May.

However, the nature of the 2020 coronavirus recessions is very different from that of the Great Depression of the 1930s and of most postwar recessions. 
Figure 2.

\section{GDP per person in the United States}

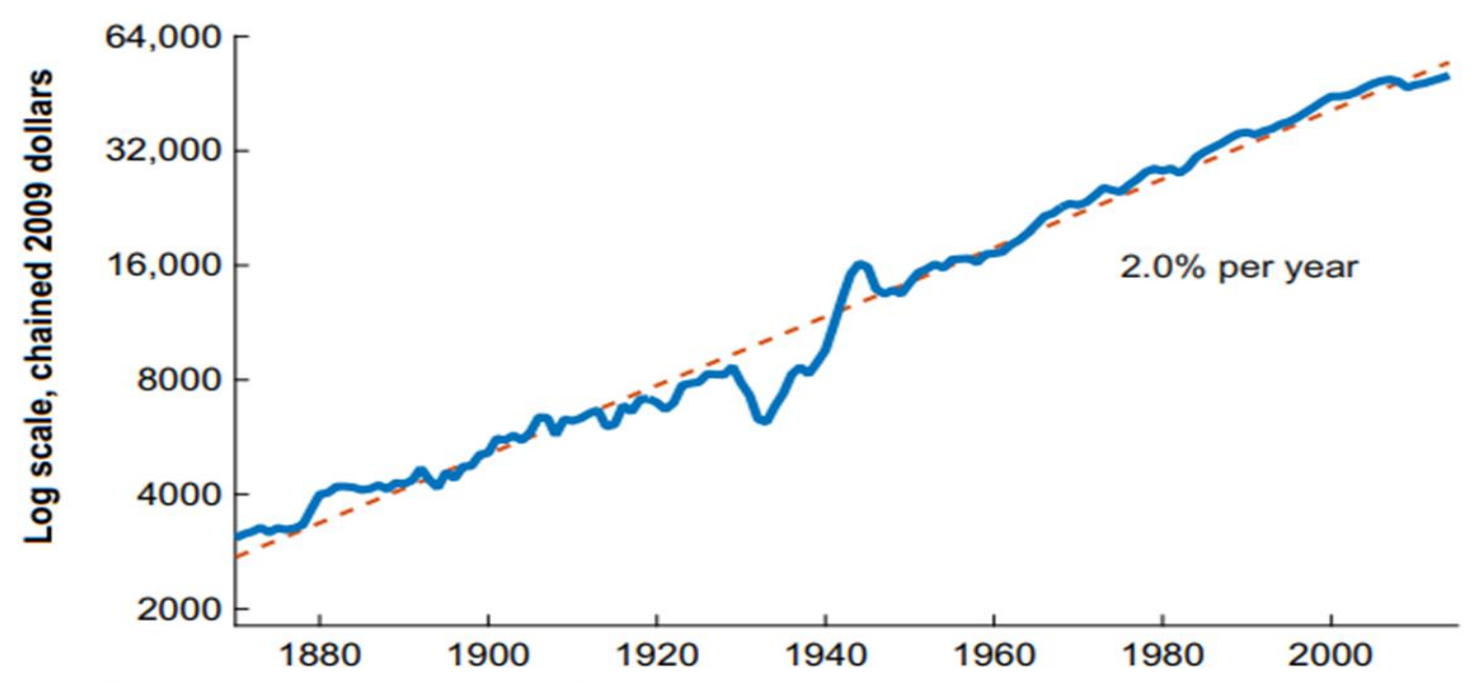

Sources: the U.S. Bureau of Economic Analysis, NIPA table 7.1. Maddison, A. 2008. Statistics on world population, http://www.ggdc.net/maddison/.

Figure 3.

United States Unemployment Rate (1890-2015)

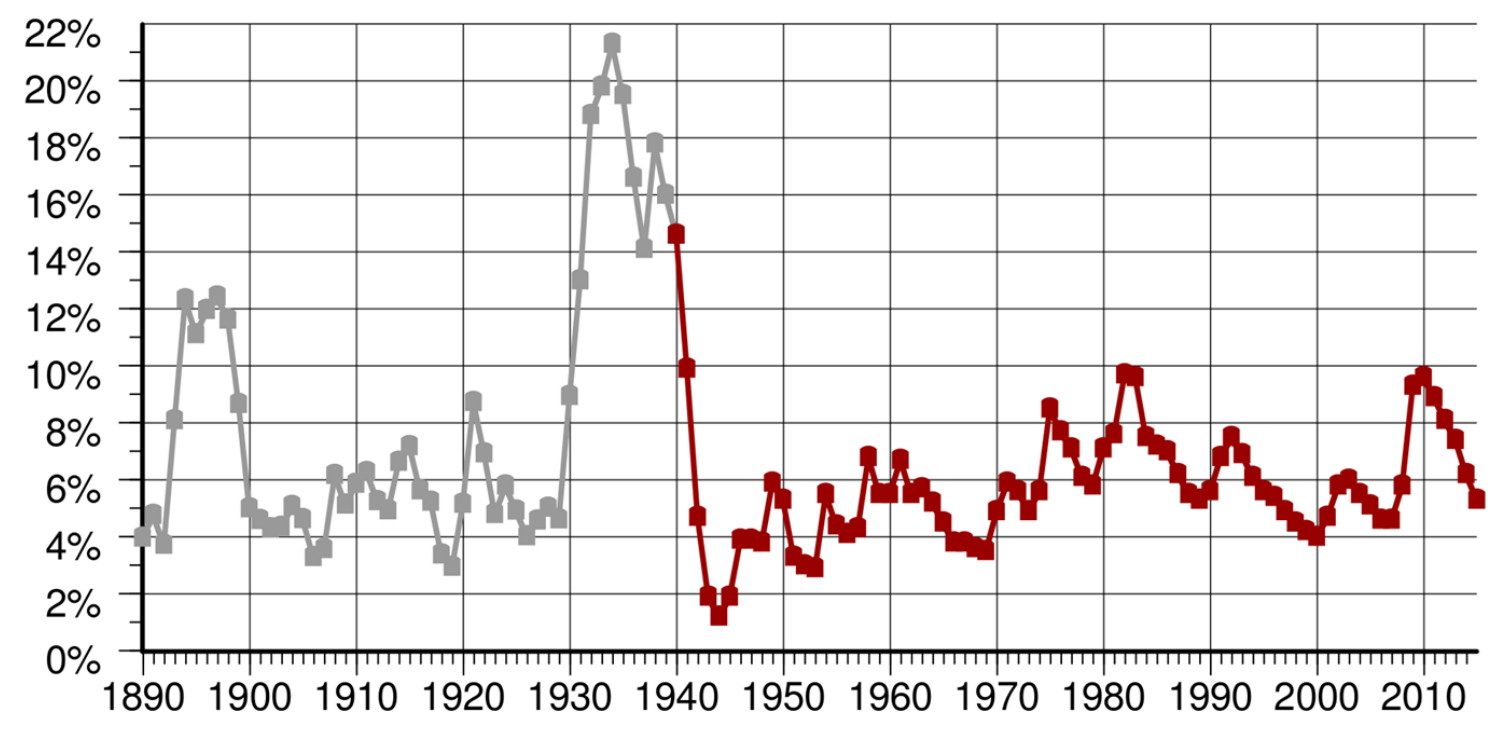

Source: Unemployment in the United States (Wikipedia, https://en.wikipedia.org/wiki/Unemployment_in_the_United_States). 


\section{Typology of recessions}

Economists distinguish between demand driven recession and supply side recession. The former is due to the shocks of demand - for instance, entrepreneurs decide to cut their investment on whatever reason, or foreign countries stop purchases of national products, so exports goes down, or households decide to postpone purchases of consumer durables. The government in this case can step in to stimulate effective demand through the expansionary fiscal and monetary policy this is the standard recommendation of the Keynesian stabilization policy

A supply side recession is usually associated with the increase in costs of production (wage increases, increase in prices of imported materials, extra costs due to unfortunate events, such as earthquakes, epidemics, wars, etc., creating bottlenecks in supplies and raising the costs of production and delivery). A particular case of the supply side recession is a structural recession caused by the need to reallocate resources, labor and capital, from one industry/region to another (Popov, 2009).

The textbook theoretical framework is the AS-AD model (see, for instance, Mankiw, 2006). The AS curve characterizes positive relationship between output and prices (the higher the prices, the larger the supply of goods), whereas AD curve characterizes the negative relationship between the demand for goods and prices.

The demand is the aggregate demand; it could be increased by the expansionary fiscal and monetary policy ( $\mathrm{AD}$ moves to the right). The supply is the aggregate supply; in the long run the AS curve is vertical (given full utilization of production capacities and labor and the level of productivity), but in the short run AS curve is positively sloped (firms respond to growing prices by expanding output and employment, but eventually this causes wages to increase, so costs catch up with growing prices and output returns to the equilibrium level). 
The negative demand shock moves the AD curve to the left, as shown on figure 4 below. Luckily, the government and the central bank can respond to the shock by expansionary fiscal and monetary policy, and can return the AD curve back at its initial position, as shown in fig. 4.

\section{Figure 4. Demand and supply shocks and government reaction}

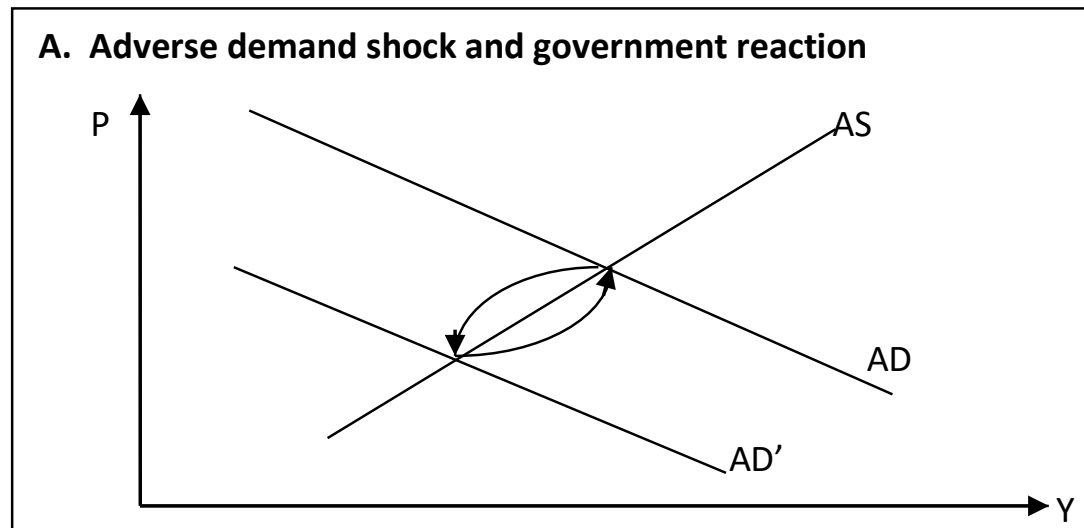

B. Absorption of the adverse supply shock

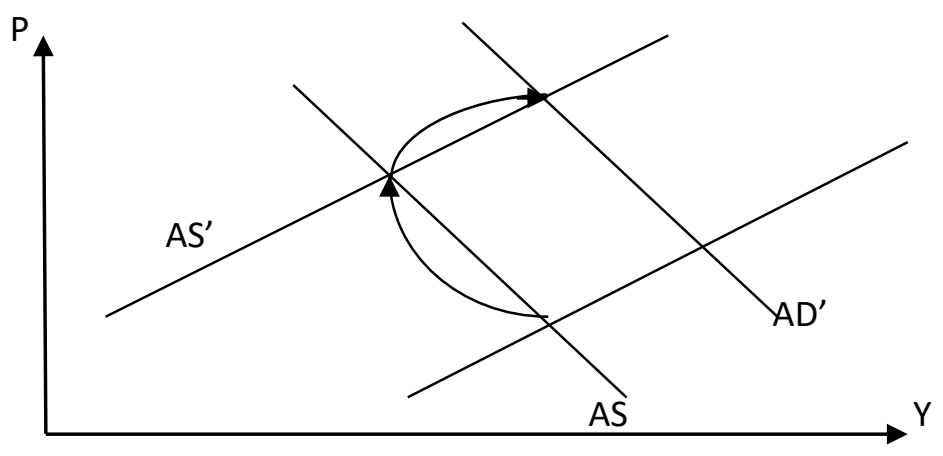

There is an agreement among economists that the Great Depression of the 1930s was caused by the demand factors (the debate is whether it was poor monetary or fiscal policy that failed to put back the AD curve). 
The negative supply shock moves the AS curve to the left (adverse supply shock). Increase in costs force the entrepreneurs to increase prices to compensate for increased costs, but at higher prices they can sell less output (so the AS curve moves to the left). The government does not have the powers to affect the position of the supply curve in the short run. The only thing the authorities can do to restore output is to increase aggregate demand (moving the AD curve to the right, restoring output at a cost of higher prices - fig. 4). This is called the absorption of the adverse supply shock.

\section{Structural and general recessions}

A general recession is the output decline in most industries (sectors, regions), whereas a structural recession is the fall in output in one industry/sector/region, which is not compensated immediately by the increase in output in another industry/sector/region. Structural recession - the one that is caused by the decline of one (non-competitive) sector and the rise of another (competitive) sector - would not be a recession at all, if the transfer of resources (capital and labor) from the first sector to the second sector would be instant and effortless. But in reality such a transfer of resources is associated with higher costs (retraining of employees, replacement of fixed capital stock), so the structural recession (whatever the initial reasons are - supply or demand shock) becomes a typical supply-side recession (Popov, 2009). The characteristic feature of the structural recession is the existence of unemployment and unloaded production capacities in some industries and the good profit opportunities in the other industries; resources eventually flow from the former to the latter industries.

Not all supply side recessions are structural. Imagine that workers ask for higher wages in all regions and industries, so that profits contract by the same amount in all companies, so they fire employees and cut output. When unemployment grows, real wages fall, profits increase and output is gradually restored to the previous level. Then there is a general supply-side recession and a recovery without the reallocation of capital and labor from one sector (industry, region) to another.

This is true with respect to demand side recessions as well. There may be a fall in demand for the products of particular industry and then there is a need to reallocate resources from this industry 
to the other sectors (structural recession). But one could imagine a demand-driven recession, caused by absolutely even contraction of demand for all products (say, due to the excess tightening of monetary policy) - in this case we have a temporary decline in output (and prices) that comes to an end as wages fall and the previous profit rate is restored at the new (lower) level of prices and wages. So, there may be recessions, supply-driven and demand-driven, not associated with the need to reallocate resources between sectors.

The important difference between the general and structural recession is that in the former case there is no need to reallocate resources, so there is no need for new investment. First, universal across industries contraction of output occurs, so that there is unemployment and unloaded production capacities; later, during recovery, employment and capacity utilization rates increase universally across industries.

Of course, every recession is a mixture of the two, but it should be possible to isolate the structural and general components in the de facto trajectories of decline and recovery of output. This in turn opens for door for the recession diagnostics. For instance, it is known that recessions in postcommunist countries were mostly structural supply side - due to changes in relative prices after deregulation (Popov, 2000; 2007). The appropriate (inappropriate) government policies could have eased (aggravated) this structural recession. It has been argued, for instance, that the impact of demand-side factors (excessively tight demand management) on output decline in Poland has been much more pronounced than the impact of supply-side factors (Rosati, 1994).

In the course of economic development structural shifts happen all the time. An example is the transition from producing musical records to cassette tapes, and then CDs, DVDs, iPods, and smartphones - all due to the introduction of new and better audio techniques. If these shifts are gradual and small scale, they do not cause a recession. But when a necessity emerges for a sudden large scale structural shift, there may very well be a recession because time and efforts are needed to reallocate resources from vanishing to emerging industries - industrial output contraction in outgoing industries is not immediately compensated by production increase in newly emerging industries. 
The infamous "cotton famine" crisis of the 1860s in Britain is a perfect example of such a structural recession. Due to the Union blockade of the Confederacy during the Civil War in the US raw cotton from the Southern US states stopped flowing freely into Britain and prices of cotton increased by several hundred percent. Textile industry of Lancashire, the backbone of British industry at the time, faced with increased costs, experienced sharp downturn, total British GDP fell, and in 1862 was over 6\% lower as compared to 1860 (Maddison, 2018).

Another example is the postwar recessions, associated with the conversion of defense industries. They occurred when defense production after the war was curtailed, but defense industries could not have been quickly converted to the production of non-defense goods. In the US after the Second World War GDP was going down for 3 years (1945-47) and in 1947 was 13\% lower than in 1944 (BEA, 2012). This is clearly visible at the fig. 2 - productivity decline in 1944-47 was the deepest after the Great Depression of the 1930s.

Recent recessions in Western countries associated with oil price peaks in 1973, 1979, and 2007 are examples of poorly managed structural shifts. In a market economy, the adjustment occurs through an increase in unemployment: industries that become unprofitable due to increased costs, lay off workers, growing unemployment contributes to a fall in wages, and only later cheap labor costs make it profitable to expand production in other industries. One could imagine government policies designed to make domestic price changes for fuel and energy very gradual, so that energy consuming enterprises could adjust by switching to energy saving technologies without cutting

output; or special subsidies to companies to facilitate "green restructuring". But without government assistance in stretching the transition period and providing stimuli for new investment, structural shifts may be difficult, painful, and costly.

\section{Transformation recession in post-communist countries in the $1990 \mathrm{~s}$}

The transformational recession that occurred in post-communist economies in the 1990s is another example of poor management of structural shifts (Popov, 2000; 2006; 2007). These involved the decline of agriculture and manufacturing and the rise of services (trade and finance) and resource 
industries. In many of these countries, the reduction of output during this transition was deeper than the one that occurred in the Great Depression of the 1930s (fig. 5).

Fig. 5. GDP change in former Soviet republics, $1989=100 \%$

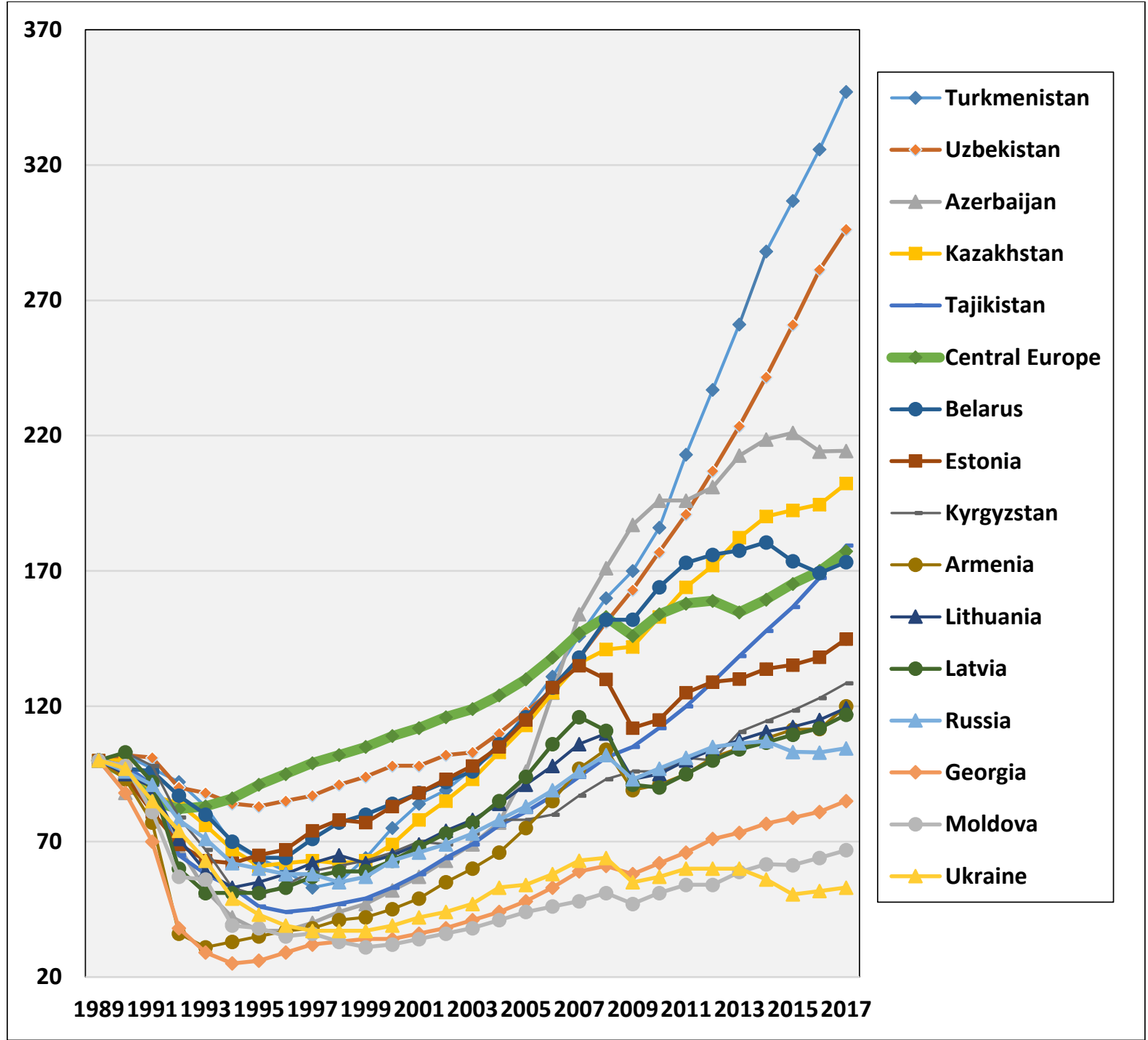

Source: EBRD Transition Report for various years.

The schematic model of the transformational recession is presented in Popov, 2000 and 2007 and is briefly described below. Imagine, there are two sectors in an economy - oil and machinery - the former is efficient and competitive, while the latter is inefficient. In a centrally planned economy 
prices were set at such levels that both sectors were profitable. Immediate deregulation of prices results in the change of relative prices - terms of trade deteriorate for machinery and improve for oil industry. Consequently, machinery sector immediately stops producing (output of machinery falls to zero) and resources (capital and labor) from this sector are moved to more profitable oil sector. However, the speed of resource reallocation is not infinite; new investment in the oil sector in a given time period (say, 1 year) can create only a fraction of jobs needed for workers moving from machinery sector enterprises that are being shut down. It will take a number of years for oil output to increase so that it is higher than the total output of machinery and oil industries combined before transformation.

On the other hand, if prices are deregulated gradually, so that only part of enterprises in machinery sector becomes unprofitable every year (say the oldest and most inefficient enterprises will go out of business first, while more efficient but still less competitive by world standards will go bankrupt only after the second, third, etc. rounds of price deregulation), then the reduction of output in machinery sector could be constantly compensated by the increase in output of oil industry. The best trajectory ${ }^{1}$, of course, is the one with such a speed of deregulation that leads to the reduction of output in the non-competitive sector at a natural rate, i.e. as its fixed capital stock retires in the absence of new investment.

The example illustrates that there is a limit to the speed of reallocating capital from noncompetitive to competitive industries, which is determined basically by the net investment/GDP ratio (gross investment minus retirement of capital stock in the competitive industries, since in non-competitive industries the retiring capital stock should not be replaced anyway). It is not reasonable to wipe away output in non-competitive industries faster than capital is being transferred to more efficient industries (Popov, 2006).

The collapse of output in the 1990s in post-communist countries of Eastern Europe and former Soviet republics is exactly this type of structural supply-side recession. It is likely to become a

\footnotetext{
${ }^{1}$ Two trajectories of the dynamics of output are shown at the graph in (Popov, 2006) under the assumption that machinery sector accounts in the year " 0 " for $20 \%$ of total output.
} 
textbook example: an excessive speed of change in relative prices required the magnitude of restructuring that was simply non-achievable with the limited pool of investment ${ }^{2}$. Up to half of reforming economies was made non-competitive overnight due to the change in relative prices after deregulation. Output in these non-competitive industries was falling for several years and fell in some cases to virtually zero, whereas the growth of output in competitive industries was constrained, among other factors, by the limited investment potential and was not strong enough to compensate for the output loss in the inefficient sectors.

Hence, at least one general conclusion from the experience of transition economies appears to be relevant for the reform process in all countries: provided that reforms create a need for restructuring (reallocation of resources), the speed of reforms should be such that the magnitude of required restructuring does not exceed the investment potential of the economy.

The speed of adjustment and restructuring in every economy is limited, if only due to the limited investment potential needed to reallocate capital stock. This is the main rationale for gradual, rather than instant, phasing out of tariff and non-tariff barriers, of subsidies and other forms of government support of particular sectors (it took nearly 10 years for the European Economic Community and for NAFTA to abolish tariffs).

The collapse of output during transition can be best explained as adverse supply shock caused mostly by a change in relative prices after their deregulation due to distortions in industrial structure and trade patterns accumulated during the period of central planning (additional adverse supply shock came from the collapse of state institutions), while the speed of liberalization, to the extent it was endogenous, i.e. determined by political economy factors, had an adverse effect on performance. In contrast, at the recovery stage the ongoing liberalization starts to affect growth positively, whereas the impact of pre-transition distortions disappears. Institutional capacity and reasonable macroeconomic policy, however, continue to be important prerequisites for successful performance (Popov, 2007). Not surprisingly, 25 years after the start of the transition the list of

\footnotetext{
2 The second major adverse supply shock during transition was associated with the decline of the institutional capacity of the state (weaker enforcement of contracts, property rights, etc. - see Popov, 2000, 2007 for details), but this was not a structural recession in a strict sense of the word because the shock affected all industries and regions more or less evenly.
} 
countries that exceeded the pre-recession level of output of 1989 included a lot of procrastinators in terms of economic liberalization: in addition to 5 central European countries and Estonia, there were also Turkmenistan, Uzbekistan, Azerbaijan, Kazakhstan, Tajikistan, and Belarus not to speak about China and Vietnam (fig. 5).

Uzbekistan is a particularly telling case. Its transformational recession was less deep than in all other FSU countries, and its dynamics of output was better than in any other former Soviet republic in the 1990s. Today its output as compared to the base of 1989 is higher than anywhere else in post-communist world except for China, Vietnam, and Turkmenistan (fig. 5). Whereas Turkmenistan's exceptional performance was based on good management of gas rent, Uzbekistan success was due to its ability to replicate Chinese and Vietnamese gradual transition and exportoriented growth strategy. After high inflation of the early 1990s, Uzbekistan carried out prudent macroeconomic policy, prevented the national currency from appreciation and carried out active industrial policy promoting important structural shifts. It moved resources from cotton production (virtually monoculture in Soviet times) into food, gas and auto industry (Popov, 2013; Chowdhury, Popov, 2016).

In the case of the coronavirus recession the choice of slowing down the speed of the resource transfer and promoting gradual restructuring instead of the immediate shutdown of some industries/enterprises is not available - travel and hospitality sectors at the very least need to be shut down immediately to save lives, so stretching the shutdown of these sectors in time was never seriously considered as a viable option. But other measures - promoting and helping businesses to transfer resources into new activities - could be useful.

\section{How to Deal with Structural Recession}

In case of the structural recession traditional Keynesian stimuli - fiscal and monetary expansion may be helpful only to the extent. Increase in government purchases of particular goods and services should lead to the increase in prices and, perhaps, an increase in production. In theory, the slump in travel, tourism, public catering and hotel businesses could be overcome by expansionary fiscal and monetary policy at the price of higher inflation. But the necessary precondition for the 
multiplier process to unfold is the existence of unloaded production capacities and unemployment. The demand stimuli that are enacted simultaneously with the supply prohibitions for many businesses can result only in price increases. As Paul Romer and Alan Garber write, "loan guarantees and direct cash transfers will stave off bankruptcy and default on debt, but these measures cannot restore the output that is lost when social distancing keeps people from producing goods and services" (Romer and Garber, 2020).

A quicker and more efficient solution is the elimination of "bottlenecks" - supply constraints by assisting and even carrying out mandatory reallocations of labor and capital. In case of corona virus pandemic, from all facilities affected by the epidemic prohibitions (travel, tourism, retail trade, sports events, restaurants, entertainment, schools, and universities, etc.) to facilities of public health, medical supplies production, emergencies and public order activities.

It is irrational to have unemployment side by side to the shortage of labor force needed to produce medical protective equipment and/or, like it happened in Europe, unemployment together with the shortage of agricultural workers for seasonal activities (these workers previously were usually coming to more developed countries from less developed countries, but encountered difficulties crossing national borders in spring 2020). For the future structure of the economy that is likely to involve less recreation services (restaurants, hotels, travel, etc.) the current coronavirus crisis should be seen as an opportunity to make much needed investment into the personnel retraining and capacity building in the health care systems making them truly universal and able to prevent and cope with any epidemics and pandemics.

Quite a few successful examples of managing structural shifts can be found in East Asia where collective interests are a high priority and governments are not afraid to resort to market intervention and direct investment financing in times of crisis. This intervention came in the form of the industrial policy, sometimes carried out through economic stimuli and sometimes even via heavy handed direct administrative orders. In China (including Hong Kong and Taiwan) and South East Asian countries it was obviously facilitated by the lessons of the SARS 2002-04 epidemic and restructuring of the health care systems carried out afterwards. 
In China, the production of protective masks increased from 15 million a day in early February 2020 to over 100 million a day by the end of the same month! Over 3,000 enterprises that previously had nothing to do with the supply of healthcare products began producing masks, protective suits, sanitizers, and other hygiene goods. Several major companies began to make masks at their enterprises: China Petroleum and Chemical Corporation, China National Machinery Industry Corporation, and the major auto manufacturers Shanghai GM Wuling, Guangzhou Automobile Group, and BYD.

The South Korean Ministry of Food and Drug Safety gave emergency approval to the company Seegene to mass produce a coronavirus test kit that it had developed in 3 weeks. All of its 395 employees dropped all other work and focused on making the test kits, with molecular biologists and senior scientists working at the assembly line.

The Vietnamese Vingroup was reported to be able to convert its automobile and smartphone factories in a period of 3 months into the production of 55,000 medical ventilators per month. The total stock of the US ventilators in March 2020 was estimated at 62,000 new and about 100,000 old; the total number of the UK ventilators at a time was 21,000 .

In Western countries in times of war, non-defense industries were converted into the production of defense items. In most countries, this happened with state assistance, which eased and sped the transition. Before and during World War II, governments normally increased taxes and borrowings and used the proceeds to purchase weapons. In the United States, the increase in defense procurements after the recession of 1937-38 caused a boom - economic growth went from negative values in 1938 to 17-20 percent growth annually in 1941-43. Never before and never after the American economy was growing that fast.

Even better results have been exhibited by centrally planned economies, which have clear advantages over market economies in mobilizing domestic savings and converting them into investment and in promoting structural shifts quickly and with full employment. In the 1930s-40s on the eve of and during World War II, the USSR transferred huge resources from agriculture to industry, from light to heavy industry, and from non-defense to defense industries. In 1940, 
Germany produced two times more steel and more defense output than the Soviet Union, but already by 1943, the USSR had surpassed Germany in the production of tanks, aircraft, and artillery guns. This structural shift was the most crucial reason that changed the course of the war.

\section{Conclusion}

The nature of coronavirus recession is a supply side shock requiring structural shifts to overcome it - transfer of capital and labor from temporary closed travel, hospitality and other affected by administrative restrictions industries to other sectors, mostly to public health and safety. The ability of countries to move resources rapidly from non-health to health-related industries is a crucial factor not only for fighting the epidemics, but also in fighting the recession. For the market mechanism to work, the increase in government orders for the ventilators should produce an increase in prices that is large enough to cover the costs of conversion, and to ensure higher profitability to compensate for the risk - only then one can expect that enterprises will introduce second and third shifts to expand their production of ventilators at the specialized plants and will make investment into the conversion of non-profile capacities into the production of ventilators.

The faster and more efficient alternative - enactment of legislations (such as Defense Production Act) to force private enterprises to switch to the production of needed equipment, no matter what are prices and costs. An extreme example of forced reallocation of resources is the labor armies created by Soviet Russia in 1920 (often employed between battles). Such labor armies are hardly possible today, but betting only on market forces to ensure equilibrium is a suboptimal approach.

The capacity to cope with the current coronavirus recession depends to a large extent on how governments will assist markets in carrying out structural shifts. As the world economy enters into a global recession in 2020 , it may be prudent for policymakers to promote radical stateinterventionist industrial policy approaches from the constructive Asian cases of the past and present. Encouraging and assisting the transfer of resources from recreation, travel and hospitality industries to health care and epidemic prevention facilities may be good not only for overcoming the current recession, but also for building stable and resilient economies and social structures of the future. 


\section{References}

Chowdhury, A. and V. Popov (2016). What Uzbekistan tells us about industrial policy that we did not know? - DESA working paper No. 147. February 2016.

BEA (Bureau of Economic Analysis), 2012. GDP and Other Major NIPA Series, 1929-2012:II

Maddison Project Database (MPD) 2018.

Mankiw, N. Gregory (2006). Macroeconomics, Sixth edition.

Popov, V. (2000). Shock Therapy versus Gradualism: The End of the Debate (Explaining the Magnitude of the Transformational Recession). - Comparative Economic Studies, Vol. 42, Spring, 2000, No. 1, pp. 1-57.

Popov, V. (2006). Why Shock Therapy May Lead To Worse Performance Than Gradual Transition. - Beyond Transition Newsletter, January-March 2006, Vol. 17, No. 1.

Popov, V. (2007). Shock therapy versus Gradualism Reconsidered: Lessons from Transition Economies After 15 Years of Reforms. - Comparative Economic Studies, Vol. 49, Issue 1, March 2007,pp. 1-31.

Popov, V. (2009). Review of "The Universal Shape of Economic Recession and Recovery after a Shock" by Damien Challet, Sorin Solomon, Gur Yaari.- "Economics. The Open-Access, OpenAssessment E-Journal", February 23, 2009.

Popov, V. (2013). An Economic Miracle in the Post-Soviet Space: How Uzbekistan Managed to Achieve What No Other Post-Soviet State Has. MPRA Paper No. 48723, posted 31 July 2013. 
Popov, V. (2020). Learning from Asia: How to Handle Coronavirus Economic Recessions. $\begin{array}{lllll}- \text { PONARS Eurasia } & \text { commentary, } & \text { April } & 28, & 2020 .\end{array}$

Rodrik, D. (2020). Making the Best of a Post-Pandemic World. Project Syndicate, May 12 , $\underline{2020 .}$

Romer, P. and A. Garber (2020). Will Our Economy Die From Coronavirus? - New York Times, March 23, 2020.

Rosati, Dariusz K. (1994). Output Decline during Transition from Plan to Market: A Reconsideration. Economics of Transition, 2 (4): 419-41, 1994. 